\title{
Effect of the oral administration of monosodium glutamate during pregnancy and breast-feeding in the offspring of pregnant Wistar rats ${ }^{1}$
}

\author{
Efeito da administração de glutamato monossódico durante a gestação e \\ amamentação na prole de ratas Wistar prenhes
}

\author{
Vinicius von Diemen ${ }^{\mathrm{I}}$, Manoel Roberto Maciel Trindade ${ }^{\mathrm{II}}$

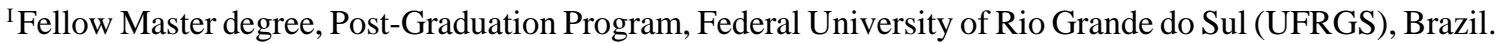

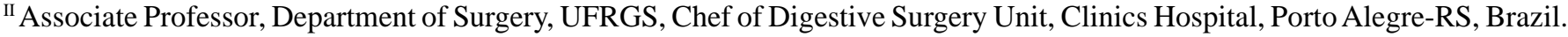

\begin{abstract}
Purpose: Determine the effects of the MSG (monosodium glutamate) in the offspring of pregnant rats through the comparison of the weight, NAL (nasal-anal length) and IL (Index of Lee) at birth and with 21 days of life. Methods: Pregnant Wistar rats and their offspring were divided into 3 groups: GC, G10 and G20. Each of the groups received 0\%, 10\% and 20\% of MSG, respectively from coupling until the end of the weaning period. Results: Neither weight nor NAL were different among the groups at birth. The group G20 at birth had an IL lower than the group GC $(\mathrm{p}<0,05)$ and with 21 days of life presented weight and NAL lower than the groups G10 and this lower than the $\mathrm{GC}(\mathrm{p}<0,01)$. Otherwise the G20 at 21 days of life had the IL similar to the other two groups. The weight profit percentage from birth to the $21^{\text {st }}$ day of life was lower in the G20 regarding the other two groups ( $\left.<<0,01\right)$. The G20 had a NAL increase percentage from birth to the $21^{\text {st }}$ day of life lower than the G10 and this lower than the GC ( $\left.<<0,01\right)$. Conclusions: MSG presented a dose-dependent relation in the variables weight and NAL. It caused a decrease in the growth pattern as well as in the weight gain pattern until the $21^{\text {st }}$ day of life. The IL of the group $20 \%$ had an increased in relation to the control group after 3 weeks of follow up.
\end{abstract}

Key words: Obesity. Sodium Glutamate. Pregnancy. Rats.

\section{RESUMO}

Objetivo: Avaliar o efeito do glutamato monossódico (GMS) nos fetos de ratas prenhes por meio da comparação do peso, comprimento nasal-anal (CNA) e índice de Lee (IL) ao nascimento e com 21 dias de vida. Métodos: Foram utilizadas ratas prenhes da linhagem Wistar distribuídas em três grupos: grupo controle (GC), G10 e G20. Estes, respectivamente, foram alimentados com ração contendo 0, 10 e $20 \%$ de GMS desde o período de acasalamento até o final da amamentação. Resultados: O peso e o CNA não foram diferentes entre os grupos ao nascimento. O grupo G20, ao nascimento, teve IL menor que o grupo GC (p < 0,05) e, aos 21 dias de vida, apresentou peso e CNA menores que o grupo G10, o qual foi menor que o GC ( $<<0,01)$. O grupo G20, aos 21 dias de vida, teve IL semelhante aos outros dois grupos. O percentual de ganho de peso do nascimento ao $21^{\circ}$ dia de vida foi menor no $\mathrm{G} 20$ em relação aos outros dois grupos (p $<0,01$ ). O grupo G20 teve percentual de aumento de CNA do nascimento ao $21^{\circ}$ dia de vida menor que o grupo G10, e este menor que o grupo GC ( $\mathrm{p}<0,01$ ). Conclusões: O GMS nas concentrações de 10 e $20 \%$ na ração de ratas prenhes Wistar apresentou uma relação dosedependente nas variáveis peso e CNA. Houve diminuição no padrão de ganho de peso e de aumento de CNA do nascimento ao $21^{\circ}$ dia de vida com uso de GMS. O IL na prole do grupo G20 aumentou em relação ao do grupo GC após 3 semanas de acompanhamento.

Descritores: Obesidade. Glutamato de Sódio. Gravidez. Ratos.

${ }^{1}$ Research performed at the Experimental Research Center, Clinics Hospital, Porto Alegre-RS, Brazil.

\section{Introduction}

Obesity can be defined as excess weight with a body mass index (BMI) higher than $30 \mathrm{~kg} / \mathrm{m}^{2}$. Morbid obesity is a much more serious condition. It is usually correlated with $170 \%$ higher weight than the ideal weight ${ }^{1}$ or, yet, a BMI higher than $40 \mathrm{~kg} / \mathrm{m}^{2}$. The number of individuals with weight above the normal is reaching epidemic proportions around the world, causing serious health damage and shorter longevity ${ }^{2}$. The etiology of obesity is multifactorial and, in many countries, it is already considered as a problem of public health, including Brazil. Obesity rates have triplicated when we analyze data from 1980, collected in North America, United Kingdom, Oriental Europe, Middle East, Pacific Islands, Australia and China ${ }^{3-6}$. The World Health Organization officially states that "obesity is responsible for 2 to $6 \%$ of the total cost of health care in several developing countries." The Brazilian situation can be best visualized through the social communication report of $12 / 16^{\text {th }} / 2004$ of the Brazilian Institute of Geography and Statistics (IBGE), in 
which the 2002-2003 Research of Family Budgets was published showing that the excess weight in the Brazilian population is already a problem of greater magnitude than malnutrition. Owing mainly to these reasons, the interest to move forward towards a wider and more advanced knowledge on the mechanisms involved in the emergence, maintenance and increase of the world's obesity has increased.

Hermanussen et $_{\text {al. }}{ }^{7}$, in an observational study held in Germany, provided evidence that morbid obese young women are of inferior stature than the average population. The same study also evidenced that the mean height of newly born babies in Germany is progressively shorter when the mother's BMI is higher than $38 \mathrm{~kg}$ / $\mathrm{m}^{2}$.

Monosodium glutamate is a non-essential amino acid found in food with great amounts of protein, such as meats, fishes, cheeses and vegetables. When detected by the taste buds, it signals the protein presence in the diet. MSG is artificially added to food to provide an expansion and extension of taste (it stimulates receptors located in taste buds) $)^{8.9}$. MSG is considered a flavorizing agent, being used thoroughly in industrialized food. Its production increased from 200.000 tons/year in 1969 to 800.000 tons/year in 2001, which reflects its crescent use in the food industry ${ }^{7,10}$. Glutamic acid (GLU), a metabolite of MSG, acts in the intermediary metabolism and as a constituent of the proteins in all the cells of the body, besides acting in the brain as an excitatory neurotransmitter. The largest amount of GLU daily ingested by humans mainly comes from the proteins of the diet. A small amount is present in food as the free glutamate and the MSG. Either this is a natural constituent of some foods, or it is added artificially as a flavorizing agent ${ }^{11}$. Researchers from around the world have been endeavoring efforts seeking the understanding of the physiopathology of obesity. One of the obesity theories is related to MSG. It is known, through experimental studies in rats that MSG administered subcutaneously in newborns leads to lesion of the hypothalamic nucleus ${ }^{12-17}$. When MSG is administered orally in female pregnant rats, it might as well cause alterations in the hypothalamus of the offspring with its consequences, such as a decrease in the secretion of GH and obesity, among others ${ }^{7,10}$. The theory of obesity related to MSG is corroborated by many factors such as the great increase on the world's production of MSG over the last decades, its growing and indiscriminating use in industrialized food, the increase in its consumption and also the progressive increase of the obesity rates throughout the continents ${ }^{3-7,18-20}$. It is believed that pregnant women are exposed to this substance, which means that they are consuming MSG more and more during the gestational period, and this could have a connection with a future obesity of the newborn, who would have suffered some kind of hypothalamic lesion while inside the uterus. A consensus on MSG from $2007^{21}$ states that the placentary barrier controls the passage of GLU from the maternal plasma to the fetus, metabolizing it before it reaches the fetal circulation. In a study with pregnant rhesus monkeys, it was shown that it would be necessary a very high serum maternal concentration of GLU, of about $2.800 \mu \mathrm{mol} / 1$, in order for the passage of GLU from the mother to the fetus to take place ${ }^{22}$.

The great similarity and homology among the genomes of the rodents and of the humans turn the animal models into an important tool for the study of conditions that affect us and that can be simulated in rats. The hypothalamic lesion caused by the parenteral administration of MSG in rats, which leads to obesity, is already known, but little is known from when it is administered orally $7,10,23$.

We conducted an unpublished study in rats when we administered MSG since the initial period of coupling and throughout the gestational period including the breast feeding period.

The objective of this study was to evaluate the effect of MSG in the fetuses of female pregnant rats during the pregnancy and the weaning period. We compared the weight, nasal-anal length (NAL) and the Lee's index (IL) at birth and with 21 days of life of the offspring of female rats fed with ration supplemented with MSG.

\section{Methods}

The Commission of Research and Ethics in Health approved this controlled experimental study, which was held in connection with the Group of Research and Post-Graduate Program of the Clinics Hospital of Porto Alegre. We followed the technical standards and international guidelines for research on animals.

Twenty nine animals of the Rattus norvegicus albinus species were used of the Wistar lineage, being 20 female rats and nine male rats in reproductive age (older than 60 days of life), coming from the Center of Animal Reproduction and Experimentation of the Laboratory of the Institute of Basic Sciences of the Health (UFRGS). The study was conducted in the Center of Research of the Clinics Hospital of Porto Alegre. The rats were individually settled in plastic boxes in a regimen of lights on and off every 12 hours. The feeding of the rats was made through triturating standard ration for rats with MSG being added in the concentrations of 0,10 and $20 \%$. The rats were divided into three groups, in accordance with the ration that they received: group control (GC), group $10 \%$ (G10) and group 20\% (G20). The ration was presented to the rats in small "coach-houses" made for such purpose. The ration and water consumption both offered freely, was measured during the whole experiment. After 7 days of coupling, the female pregnant rats were placed in separate boxes. Alimentary and water control became individual and daily until the date of the birth, always at noon.

On the day of the birth and until the $21^{\text {st }}$ day of life, weight, NAL and consumption of water and ration checks were conducted. At the end of this period, the nestlings were anesthetized with isoflurane ${ }^{24}$ for new checks and submitted to euthanasia through the $\mathrm{CO}^{2}$ chamber.

\section{Statistical analysis}

The quantitative variables were described by the mean and standard deviation. These variables were compared among the groups by the test of variance analysis (ANOVA) followed by the Tukey test to conduct multiple comparisons. The ANOVA test for repeated measures compared the means through time and the variation in the time of the groups. A 5\% significative level was used.

\section{Results}

After 20 females were placed in coupling, we obtained 14 female pregnant rats and a total of 121 births, in accordance to Figure 1.

Weigh (in $\mathrm{g}$ ) and NAL (in $\mathrm{cm}$ ) on the day of the birth with its respective means and standard deviations can be visualized in Table 
1. There was no difference in these parameters at birth in the comparison among the groups.

The weight (in $\mathrm{g}$ ) and NAL (in $\mathrm{cm}$ ) on the $21^{\text {st }}$ day of life with its respective means and standard deviations were: $25,2(3,14) ; 23,2$ $(2,08)$ and $16,6(1,97)(\mathrm{p}<0,01)$ and $9,4(0,44) ; 9,1(0,26)$ and $8,1(0,34)$ $(\mathrm{p}<0,01)$ in the respective groups GC, G10 and G20. After comparison of the groups in pairs (Tukey test), we verified that the three groups are different from one another and they present decreasing values for weight increase and NAL in the following order: group GC, G10 and G20, according to Table 1 .

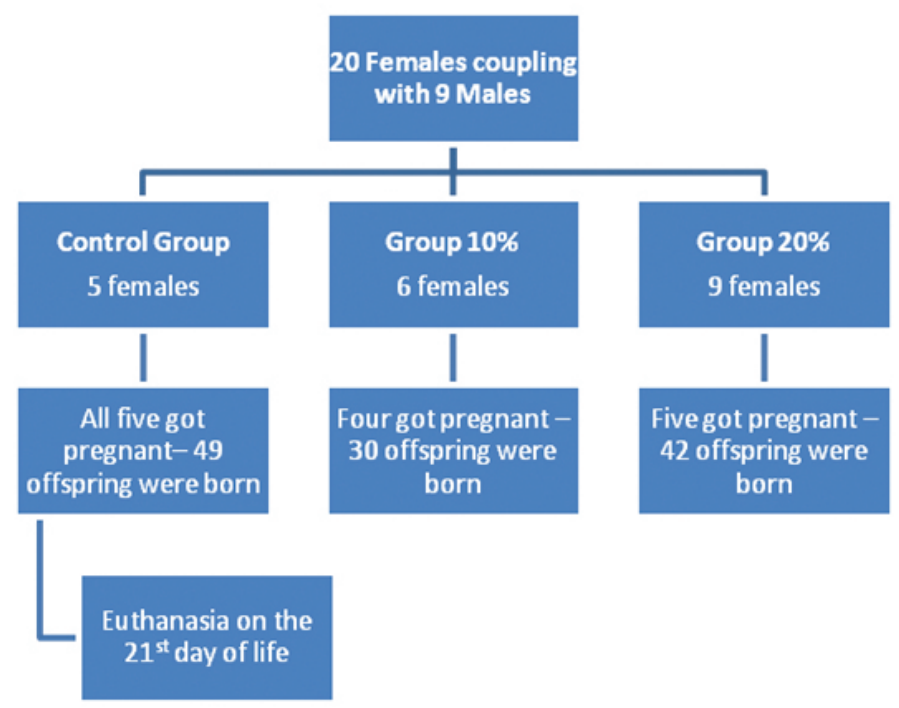

FIGURE 1 - Fluxogram with the formation of the groups with the number of rats which coupled, the number of pregnant rats and the number of offspring which had been born

TABLE 1 - Weight, NAL and IL at birth and at 21 days of life of the offspring of rats which had a consumption of ration with MSG being added in the concentrations of $20 \%$ (Group 20\%), 10\% (Group $10 \%$ ) and pure ration (Control Group)

\begin{tabular}{|c|c|c|c|c|}
\hline & $\begin{array}{c}\text { CONTROL } \\
\text { GROUPS } \\
\text { Mean }\left(S D^{*}\right)\end{array}$ & $\begin{array}{c}\text { GROUP } \\
10 \% \\
\text { Mean (SD) }\end{array}$ & $\begin{array}{c}\text { GROUP } \\
20 \% \\
\text { Mean }(S D)\end{array}$ & $\begin{array}{c}A N O V A \\
P\end{array}$ \\
\hline Weight birth & $6,08(0,52)$ & $6,03(0,61)$ & $5,84(0,49)$ & 0,091 \\
\hline NAL birtth & $4,98(0,27)$ & $5,03(0,21)$ & $5,02(0,24)$ & 0,61 \\
\hline $\mathrm{IL}^{1}$ birtth & $367(17,2)^{\mathrm{a} * *}$ & $361,4(9,2)$ & $358,8(12,2)^{b}$ & $<0,05$ \\
\hline Weight $21 d^{2}$ & $25,2(3,14)^{\mathrm{a}}$ & $23,2(2,08)^{b}$ & $16,6(1,97)^{c}$ & $<0,01$ \\
\hline $\mathrm{NAL}^{3} 21 \mathrm{~d}$ & $9,4(0,44)^{a}$ & $9,1(0,26)^{b}$ & $8,1(0,34)^{c}$ & $<0,01$ \\
\hline IL 21d & $311(9,65)$ & $314,8(5,27)$ & $313,3(4,6)$ & 0,179 \\
\hline
\end{tabular}

Comparison of the groups with ANOVA followed by Tukey for multiple comparisons, where $* * a \neq b \neq c$ for $\mathrm{p}<0,05$.

*ST=standard deviation

$1=$ index of Lee, 2 = days, $3=$ nasal-anal length in $\mathrm{cm}$

IL is equivalent in rats to the BMI used in humans. At birth and with 21 days of life for the groups GC, G10 and G20 with mean and standard deviation, the values of IL were, respectively, 367 $(17,2) ; 361,4(9,2)$ and $358,8(12,2)(\mathrm{p}<0,05)$ and $311(9,65) ; 314,8$
$(5,27)$ and $313,3(4,6)$. At birth, there were only differences among the groups GC and G20, in accordance to Table 1 and Figure 2.

The weight increase percentage from birth to the $21^{\text {st }}$ day of life among the three groups presented difference among the groups GC and G10 compared to G20 ( $p<0,01$ ), which had lower gain percentage than the others, as summarized in Figure 3.

The NAL increase percentage from birth to the $21^{\text {st }}$ day of life among the groups evidences a decreasing gain percentage among the groups GC, G10 and G20, respectively ( $\mathrm{p}<0,01$ ), according to data presented in Figure 4.

The ration consumption had mean and standard deviation of 22,6 $\mathrm{g}(7,25) ; 24,8 \mathrm{~g}(6,49)$ and 22,4 $\mathrm{g}(5,92)$ in the groups GC, G10 and G20, respectively (Table 2). There was no statistical difference among the groups.

The average consumption (standard deviation) of water in $\mathrm{ml}$ was of $42,1(12,02) ; 62,8(10,77)$ and $73,0(23,71)$, respectively, in the groups GC, G10 and G20 (p<0,01). The consumption of water was increasing among the groups GC, G10 and G20, in that order, as data presented in Table 2 .

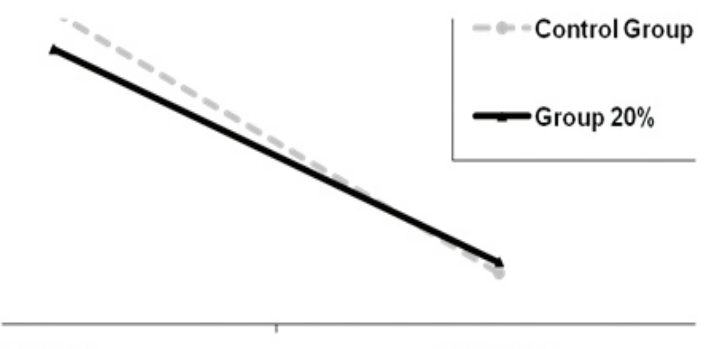

Leel Birth Leel 21 days

FIGURE 2 - Lee Index at birth (Lee I Birth) $(\mathrm{p}<0,05)$ and at 21 days of life (Lee I 21 days) $(p=0,179)$ of the offspring of rats with MSG being added in the concentrations of 20\% (Group 20\%) and pure ration (Control Group)

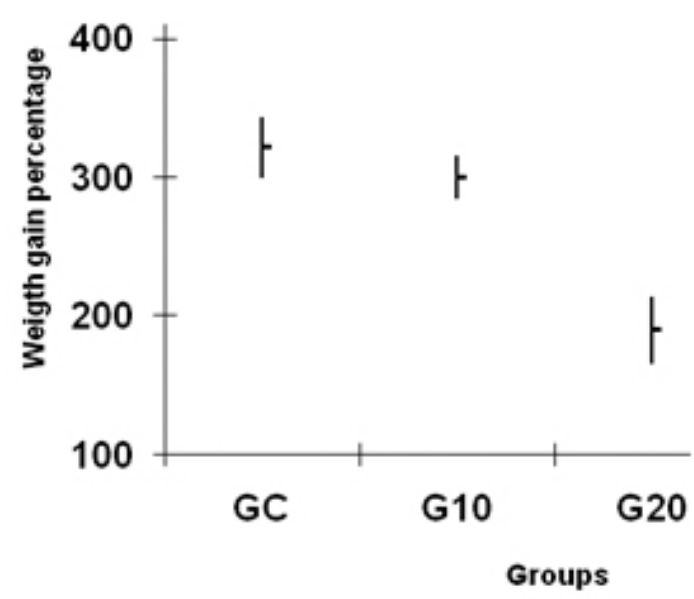

FIGURE 3 - Percentage of weight gain from birth until the $21^{\text {st }}$ day of life of the offspring of rats which had a consumption of ration with MSG being added in the concentrations of $20 \%(\mathrm{G} 20), 10 \%$ (G10) and pure ration (GC), where GC and G10 groups showed higher weight gain percentage than the G20 group ( $p<0,01)$ 


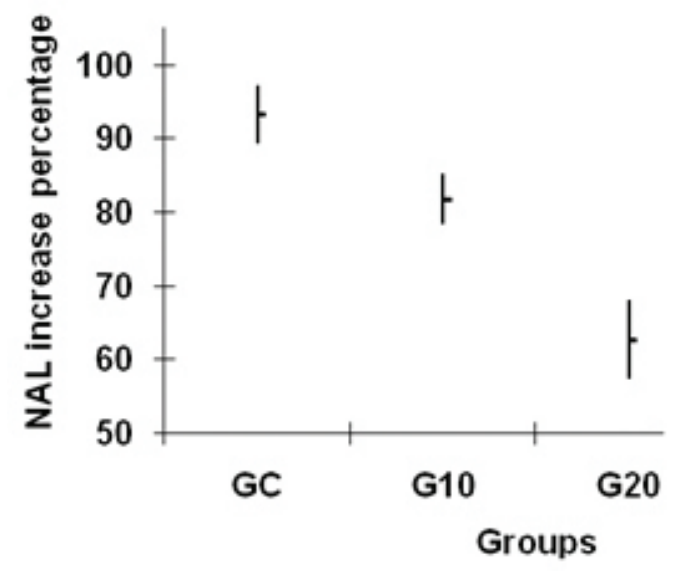

FIGURE 4 - Percentage of NAL increase from birth until the $21^{\text {st }}$ day of life of the offspring of rats which had a consumption of ration with MSG being added in the concentrations of $20 \%$ (G20), $10 \%$ (G10) and pure ration (GC), decreasing among the groups GC, G10 and $\mathrm{G} 20$, respectively $(\mathrm{p}<0,01)$ the small magnitude of the measure (tenth of grams) and relatively small size of the sample.

Weight and NAL data besides being analyzed separately were also assessed through IL and through the increase percentage from birth to the $21^{\text {st }}$ day of life. IL is equivalent, for rats as the BMI used in humans, which takes into consideration the mass distribution through the body surface. IL in rats is calculated through the cubic root of the weight (in g) divided by the height (in $\mathrm{cm}$ ) (nasal-anal distance - NAL) and multiplied by $1.000^{25-27}$. IL at birth in the GC is significantly larger than the one in the G20 (p < $0.05)$. However, when we followed these rats until the $21^{\text {st }}$ day of life, we noticed that the growth (NAL) and the weight increase do not occur in the same way in those two groups, because IL with 21 days is similar among them, in other words, in this period the group G20 gained more body mass, related to its body surface, in comparison to group GC. This shows an increase in the IL in the rats of mothers fed with ration supplemented with $20 \%$ of MSG until the $21^{\text {st }}$ day of life. Stretching these data to the future, we would have an increase tendency in the IL of rats of the group G20 throughout the time.

TABLE 2 - Weight and NAL increase percentage from birth until the $21^{\text {st }}$ day of life of the offspring of rats which had a consumption of ration with MSG being added in the concentrations of $20 \%$ (Group 20\%), 10\% (Group 10\%) and pure ration (Control Group). Consumption of ration and water of pregnant rats on the gestational period among Group 20\%, Group 10\% and Control Group

\begin{tabular}{|c|c|c|c|c|}
\hline & $\begin{array}{c}\text { GROUP } \\
\text { CONTROLS } \\
\text { Mean (ST*) }\end{array}$ & $\begin{array}{c}\text { GROUP } \\
10 \% \\
\text { Mean }(S T) \\
\end{array}$ & $\begin{array}{c}\text { GROUP } \\
20 \% \\
\operatorname{Mean}(\mathrm{ST}) \\
\end{array}$ & $\begin{array}{c}A N O V A \\
P\end{array}$ \\
\hline Ration consumption in $\mathrm{g}^{1}$ & $22,6(7,25)$ & $24,8(6,49)$ & $22,4(5,92)$ & $\mathrm{O}, 14$ \\
\hline Water consumption in $\mathrm{ml}^{2}$ & $42,1(12,02)^{a}$ & $62,8(10,77)^{b}$ & $73,0(23,71)^{c}$ & $<0,01$ \\
\hline
\end{tabular}

Comparison of the groups with ANOVA followed by Tukey for multiple comparisons, where *** $\mathrm{a} \neq \mathrm{b} \neq \mathrm{c}$ for $\mathrm{p}<0,05$.

$* \mathrm{ST}=$ standard desviation

$1=$ grams and $2=$ milliliters

\section{Discussion}

Data analysis shows that both weight and NAL of the offspring with 21 days of life are significantly lower when G20 is compared to G10, and this is compared to GC. These two measures present alterations according to the concentration of MSG on the diet, in other words, according to the increase of MSG (10 and 20\%) there was a decrease on the weight and NAL at 21 days of life. Weight and NAL at birth among the three groups did not differ significantly. However, in the gross analysis of the data, we can observe that the weight at birth of G20 seems lower than the other groups. Perhaps that difference has not been demonstrated due to
These data are in accordance to what one would expect to find in the literature $7,25,27$. Hermanussen et al. ${ }^{7}$, administering MSG on the 3rd week of gestation, has shown similar results with lower weight at birth and with 30 days of life in the intervention group, using a dose of $5 \mathrm{~g}$ of MSG orally. This dose is close to the one we used in the group $20 \%$, that consumed around $22 \mathrm{~g}$ of ration a day, about $4,5 \mathrm{~g}$ of MSG. Nakagawa et al. ${ }^{25}$ used MSG intraperitoneal in the newly born and assessed at 10 weeks of life. They also evidenced lower weight and stature and higher IL in relation to the controls. Souza et l. $^{27}$, using MSG subcutaneously in newly born, found, already in the 30th day of life, lower NAL and higher IL in the intervention group in relation to the control. 
The NAL increase percentage from the day of birth to the $21^{\text {st }}$ day of life evidences that the G20 group has significantly lower growth than the G10 and this is lower than the GC. We observed a dose-dependent curve in relation to MSG, since the growth percentage of the G10group, besides being different from G20 and GC, presents an intermediate value among them (Figure 4).

According to weight increase percentage, we verified a tendency that can also have a dose-dependent relationship. In spite of there not being statistical difference between G10 and the other groups, G10 has an intermediate absolute value between GC and G20, which are statistically different $(\mathrm{p}<0,01)$ (Figure 3$)$. These findings are similar to the ones from Hermanussen et al. ${ }^{7}$, that found difference in the weight of mothers nestlings fed with concentrations between 2,5 and 5g of MSG. As already mentioned above, we used doses of MSG in this study very close to the ones used by Hermanussen et al. ${ }^{7}$ The Tingxi Yu et al. ${ }^{28}$ study, on the other hand, did not find dose-dependence relationship in the fetuses on the two used doses, which were around 0.62 and $1 \mathrm{~g}$ of MSG on the female pregnant rats from the $17^{\text {th }}$ to the $21^{\text {st }}$ day of gestation and during the whole gestational period.

Findings in literature analyzing MSG and the consumption of ration are conflictive. Some studies demonstrate decrease on the ration consumption in the group that uses $\mathrm{MSG}^{25,29,30}$ and in others, an increase on the consumption is seen ${ }^{7,9,10}$. Articles, which demonstrate hypophagia with the use of MSG, used neonatal subcutaneous administration and evaluated the appetite after 10 and 20 weeks or after 30 to 150 days of intervention ${ }^{25,29,30}$. Those that evidenced higher consumption used MSG orally, and Diniz et al. ${ }^{9}$ began the intervention with 21 days of life and assessed the consumption after 45 days. Other two articles ${ }^{7,10}$ used MSG in the gestation, starting from the 2 nd and 3 rd weeks of gestation. The first measured the consumption starting from 30 days of life up to 90 days, and the second assessed in 90 days of life. All those studies assessed the ration consumption of the nestlings after the weaning period. Literature shows that MSG given to rats orally increases its overall ration consumption after the weaning period. We did not find in the literature whether the addition of MSG in the ration of female pregnant rats would modify its own consumption. There was no difference on the alimentary consumption among the three groups of female pregnant rats. This information corroborates the results of the present study, because, if there was difference, it could slant both the weight and the NAL results of the newly born, acting as a confusing factor.

In the literature, regarding the consumption of food and water, there is only reference to offspring after the weaning period, when there is more consumption of water with the use of MSG in the maternal ration on the $3^{\text {rd }}$ week of gestation ${ }^{7}$. We assessed the ingestion of water of the female pregnant rat during gestation. There was a dose-dependent relationship, because the consumption of water was increasing among the groups GC, G10 and G20. We do not believe that this data might have influenced the main outcomes of the study. The higher consumption of water parallel to the concentration of MSG in the ration is probably related to the sodium component in MSG.
Olney $^{31}$, using subcutaneous injection of MSG in newly born rats, related sterility of the females. Tingxi Yu et al..$^{28}$ administered MSG orally for pregnant female rats in the end of gestation and did not find alteration in the fertility of the offspring. Stegink ${ }^{22}$, evaluating the placentary transfer of MSG in monkeys, showed that the placenta would be virtually MSG proof and it would just allow the passage of its metabolites. However, doses 70 times beyond the normal, about $2.800 \mu \mathrm{mol} / 1$ resulted in transfer to the fetal circulation. In spite of some conflictive data in animals ${ }^{32-35}$, the consensus on MSG claims to be a rational safety on the use of MSG during gestation in humans. We used a small number of pregnant females in order to state there are some interference on the reproductive apparatus from the use of MSG. However, from the gross data point of view, we observed that the success percentage on coupling was very different from GC (100\%) in relation to the G10 and G20groups, respectively, 66 and $55 \%$. In relation to G20, in which four female rats were not pregnant, a possible explanation, at least partly, it the fact that three of those were came from the same box, in other words, they were exposed to the same male rat.

\section{Conclusions}

The monosodium glutamate presented a dose-dependent relation in the variables weight and nasal-anal length. It caused a decrease in the growth pattern as well as in the weight gain pattern until the $21^{\text {st }}$ day of life. The Index of Lee of the group $20 \%$ had an increased in relation to the control group after three weeks of follow up.

\section{References}

1. Nagle AP, Prystowsky JB. Surgical management of obesity. Clin Obstet Gynecol. 2004;47(4):928-41.

2. Livingston EH. Obesity and its surgical management. Am J Surg. 2002;184(2):103-13.

3. Baskin ML, Ard J, Franklin F, Allison DB. Prevalence of obesity in the United States. Obes Rev. 2005;6(1):5-7.

4. Thorburn AW. Prevalence of obesity in Australia. Obes Rev. 2005;6(3):187-9.

5. Rennie KL, Jebb SA. Prevalence of obesity in Great Britain. Obes Rev. 2005;6(1):11-2.

6. Asia Pacific Cohort Studies Collaboration. The burden of overweight and obesity in the Asia-Pacific region. Obes Rev. 2007;8(3):191-6.

7. Hermanussen M, Garcia AP, Sunder M, Voigt M, Salazar V, Tresguerres JA. Obesity, voracity, and short stature: the impact of glutamate on the regulation of appetite. Eur J Clin Nutr. 2006;60(1):25-31.

8. Taylor-Burds CC, Westburg AM, Wifall TC, Delay ER. Behavioral comparisons of the tastes of $\mathrm{L}$-alanine and monosodium glutamate in rats. Chem Senses. 2004;29(9):807-14.

9. Diniz YS, Faine LA, Galhardi CM, Rodrigues HG, Ebaid GX, Burneiko RC, Cicogna AC, Novelli EL. Monosodium glutamate in standard and high-fiber diets: metabolic syndrome and oxidative stress in rats. Nutrition. 2005;21(6):749-55.

10. Fernandez-Tresguerres Hernandez JA. [Effect of monosodium glutamate given orally on appetite control (a new theory for the obesity epidemic)]. An R Acad Nac Med (Madr). 2005;122(2):341-55.

11. Fernstrom JD. Pituitary hormone secretion in normal male humans: acute responses to a large, oral dose of monosodium glutamate. J Nutr. 2000;130(4S Suppl):1053S-7S. 
12. Dolnikoff M, Martin-Hidalgo A, Machado UF, Lima FB, Herrera E. Decreased lipolysis and enhanced glycerol and glucose utilization by adipose tissue prior to development of obesity in monosodium glutamate (MSG) treated-rats. Int J Obes Relat Metab Disord. 2001;25(3):426-33. 13. de Mello MA, de Souza CT, Braga LR, dos Santos JW, Ribeiro IA, Gobatto CA. Glucose tolerance and insulin action in monosodium glutamate (MSG) obese exercise-trained rats. Physiol Chem Phys Med NMR. 2001;33(1):63-71.

14. de Souza CT, Nunes WM, Gobatto CA, de Mello MA. Insulin secretion in monosodium glutamate (MSG) obese rats submitted to aerobic exercise training. Physiol Chem Phys Med NMR. 2003;35(1):43-53.

15. Kanarek RB, Meyers J, Meade RG, Mayer J. Juvenile-onset obesity and deficits in caloric regulation in MSG-treated rats. Pharmacol Biochem Behav. 1979;10(5):717-21.

16. Shivshankar P, Devi SC. Screening of stimulatory effects of dietary risk factors on mouse intestinal cell kinetics. World J Gastroenterol. 2005;11(2):242-8.

17. Bunyan J, Murrell EA, Shah PP. The induction of obesity in rodents by means of monosodium glutamate. Br J Nutr. 1976;35(1):25-39.

18. Filozof C, Gonzalez C, Sereday M, Mazza C, Braguinsky J. Obesity prevalence and trends in Latin-American countries. Obes Rev. 2001;2(2):99106.

19. Carmo Id, dos Santos O, Camolas J, Vieira J, Carreira M, Medina L, Reis L, Galvao-Teles A. Prevalence of obesity in Portugal. Obes Rev. 2006;7(3):233-7.

20. Rashidi A, Mohammadpour-Ahranjani B, Vafa MR, Karandish M. Prevalence of obesity in Iran. Obes Rev. 2005;6(3):191-2.

21. Beyreuther K, Biesalski HK, Fernstrom JD, Grimm P, Hammes WP, Heinemann U, Kempski O, Stehle P, Steinhart H, Walker R. Consensus meeting: monosodium glutamate - an update. Eur J Clin Nutr. 2007;61(3):304-13.

22. Stegink LD, Pitkin RM, Reynolds WA, Filer LJ, Jr., Boaz DP, Brummel MC. Placental transfer of glutamate and its metabolites in the primate. Am J Obstet Gynecol. 1975;122(1):70-8.

23. Frieder B, Grimm VE. Prenatal monosodium glutamate (MSG) treatment given through the mother's diet causes behavioral deficits in rat offspring. Int J Neurosci. 1984;23(2):117-26.

24. Meguid MM, Ramos EJ, Suzuki S, Xu Y, George ZM, Das UN, Hughes K, Quinn R, Chen C, Marx W, Cunningham PR. A surgical rat model of human Roux-en-Y gastric bypass. J Gastrointest Surg. 2004;8(5):621-30.
25. Nakagawa T, Ukai K, Ohyama T, Gomita Y, Okamura H. Effects of chronic administration of sibutramine on body weight, food intake and motor activity in neonatally monosodium glutamate-treated obese female rats: relationship of antiobesity effect with monoamines. Exp Anim. 2000;49(4):239-49.

26. Li H, Matheny M, Nicolson M, Tumer N, Scarpace PJ. Leptin gene expression increases with age independent of increasing adiposity in rats. Diabetes. 1997;46(12):2035-9.

27. Souza F, Marchesini JB, Campos AC, Malafaia O, Monteiro OG, Ribeiro FB, Alves HFP, Siroti FJ, Meister H, Mathias PCF. Efeito da vagotomia troncular em ratos injetados na fase neonatal com glutamato monossódico: estudo biométrico. Acta Cir Bras. 2001;16:32-45.

28. Yu T, Zhao Y, Shi W, Ma R, Yu L. Effects of maternal oral administration of monosodium glutamate at a late stage of pregnancy on developing mouse fetal brain. Brain Res. 1997;747(2):195-206.

29. Kim YW, Choi DW, Park YH, Huh JY, Won KC, Choi KH, Park SY, Kim JY, Lee SK. Leptin-like effects of MTII are augmented in MSGobese rats. Regul Pept. 2005;127(1-3):63-70.

30. Perello M, Gaillard RC, Chisari A, Spinedi E. Adrenal enucleation in MSG-damaged hyperleptinemic male rats transiently restores adrenal sensitivity to leptin. Neuroendocrinology. 2003;78(3):176-84.

31. Olney JW. Brain lesions, obesity, and other disturbances in mice treated with monosodium glutamate. Science. 1969;164(880):719-21.

32. Rodriguez-Sierra JF, Sridaran R, Blake CA. Monosodium glutamate disruption of behavioral and endocrine function in the female rat. Neuroendocrinology. 1980;31(3):228-35.

33. Bakke JL, Lawrence N, Bennett J, Robinson S, Bowers CY. Late endocrine effects of administering monosodium glutamate to neonatal rats. Neuroendocrinology. 1978;26(4):220-8.

34. Pizzi WJ, Barnhart JE, Fanslow DJ. Monosodium glutamate admlinistration to the newborn reduces reproductive ability in female and male mice. Science. 1977;196(4288):452-4.

35. Lengvari I. Effect of perinatal monosodium glutamate treatment on endocrine functions of rats in maturity. Acta Biol Acad Sci Hung. 1977;28(1):133-41.

\section{Acknowledgments}

Angélica Sauthier, Greyce Berton and Vanessa L. Almeida participated on execution of this research.

\section{Correspondence:}

Vinicius von Diemen

Rua Felipe de Oliveira, 566/804

90630-000 Porto Alegre - RS Brazil

Phone: (55 51)3061-8892 / 8404-9251

Fax:(55 51)3331-7143

viniciusvon@hotmail.com

Conflict of interest: none Financial source: Fipe and $\mathrm{CNPq}$

Received: August 18, 2009

Review: October 22, 2009

Accepted: November 24, 2009

\section{How to cite this article}

von Diemen V, Trindade MRM. Effect of the oral administration of monosodium glutamate during pregnancy and breast-feeding in the offspring of pregnant Wistar rats. Acta Cir Bras. [serial on the Internet] 2010 Jan-Feb;25(1). Available from URL:

http://www.scielo.br/acb 